\title{
Analisis Normatif Terhadap Putusan Praperadilan No. 04/PID.PRAP/2015/PN. \\ Berdasarkan Prespektif Kemanfaatan, Kepastian Hukum dan Keadilan
}

\author{
Mukharom ${ }^{1}$, Dhian Indah Astanti², Dewi Tuti Muryati ${ }^{3}$. \\ Universitas Semarang \\ Jl. Soekarno Hatta Tlogosari Semarang \\ mukharoms2@yahoo.co.id \\ Masuk: 14 Mei 2020; Diterima: 27 Mei 2020; Terbit: 29 Mei 2020. \\ DOI: $10.24905 /$ diktum.v8i1.89
}

\begin{abstract}
The objective of the law according to Gustav Radbruch, namely justice, certainty, and benefit, this goal is the benchmark of writing in reviewing pretrial judgment. One of the decisions of the pretrial considered controversial is the verdict No. 04/Pid. Prap./2015/PN. Jaksel on February 16, 2015 submitted by the applicant Kom. Jen police Drs. Budi Gunawan against the Corruption Eradication Commission (KPK) that has established the applicant as a corruption criminal act suspect. The sole judge Sarpin Rizaldi in the case of the pretrial granted the lawsuit filed by the applicant and defeated the KPK. Normative legal certainty is when a rule is made and is reacted for certainty as it regulates clearly and logically. It is obvious in the sense that it does not pose to doubt (multi-interpretation) and logically in the sense of being a system of norms so as not to clash or lead to conflict norms. The problems studied include how the Basic law of the pretrial Judge Sarpin Rizaldi decides the issue and whether the pretrial decision No. 04/Pid. Prap/2015/PN. Jaksel has the legal objectives of justice, legal certainty and benefits. The research method to be used is through normative juridical approaches, research specifications using descriptive analysis, the data used is secondary data which includes primary legal material, secondary legal material, tertier legal material, which is then analyzed qualitatively. Based on the results of the research is known that the step of the judge Prapertual doing rechtsvinding is correct and indeed should be so, because one of the reasons for the need to do the discovery of the law by the judge has been fulfilled, the regulation does not exist, or the rules exist but less Even without the reasons, a judge is still considered to be a legal discovery (in a narrow sense) that when it finds a match between the intent or sound of legislation with the qualifications of the event or its contrivance case.
\end{abstract}

Keywords: normative analysis, pretrial, justice, legal certainty, Benefits. 


\begin{abstract}
Abstrak
Tujuan hukum menurut Gustav Radbruch yaitu keadilan, kepastian, dan kemanfaatan, tujuan ini menjadi tolak ukur penulisan dalam mengkaji putusan praperadilan. Salah satu Putusan Praperadilan yang dianggap kontroversial adalah Putusan No. 04/Pid.Prap./2015/PN.Jaksel tanggal 16 Februari 2015 yang diajukan oleh Pemohon Kom.Jen Polisi Drs. Budi Gunawan melawan Komisi Pemberantasan Korupsi (KPK) yang telah menetapkan Pemohon sebagai tersangka tindak pidana korupsi. Hakim tunggal Sarpin Rizaldi dalam perkara Praperadilan tersebut mengabulkan gugatan yang diajukan Pemohon dan mengalahkan KPK. Kepastian hukum secara normatif adalah ketika suatu peraturan dibuat dan diundangkan secara pasti karena mengatur secara jelas dan logis. Jelas dalam artian tidak menimbulkan ke ragu-raguan (multi-tafsir) dan logis dalam artian menjadi sistem norma sehingga tidak berbenturan atau menimbulkan konflik norma. Permasalahan yang dikaji diantaranya Bagaimana dasar hukum hakim Praperadilan Sarpin Rizaldi memutuskan perkaranya dan Apakah putusan Praperadilan No. 04/Pid.Prap/2015/PN.Jaksel telah susuai dengan tujuan hukum yaitu keadilan, kepastian hukum dan kemanfaatan. Metode penelitian yang akan dipergunakan adalah melalui pendekatan yuridis normatif, spesifikasi penelitian menggunakan deskriptif analisis, data yang digunakan adalah data sekunder yang meliputi bahan hukum primer, bahan hukum sekunder, bahan hukum tertier, yang kemudian dianalisis secara kualitatif. Berdasarkan hasil penelitian diketahui bahwa langkah hakim Praperadilan melakukan rechtsvinding sudah tepat dan memang sudah seharusnya demikian, karena salah satu beberapa alasan perlunya melakukan penemuan hukum oleh hakim telah terpenuhi yaitu peraturan tidak ada, atau peraturannya ada tapi kurang jelas. Bahkan tanpa alasan-alasan tersebut pun, seorang hakim tetap dianggap melakukan penemuan hukum (dalam arti sempit) yaitu ketika ia menemukan kecocokan antara maksud atau bunyi peraturan perundangundangan dengan kualifikasi peristiwa atau kasus konkritnya.
\end{abstract}

Kata Kunci: Analisa normatif, Praperadilan, Keadilan, Kepastian Hukum, Kemanfaatan.

\title{
A. Pendahuluan
}

Pada awal tahun 2015 hukum Indonesia kembali diuji, berawal dari ditetapkannya Komjen Budi Gunawan sebagai tersangka oleh Komisi Pemberantasan Korupsi (KPK) yang menuai banyak polemik dan spekulasi berkepanjangan sampai sekarang, perseteruan tersebut sering disebut "Cicak Melawan Buaya". Praperadilan bagi kebanyakan masyarakat sebelum munculnya kasus Budi Gunawan masih sangat awam dan jarang sekali yang tahu, setelah ada kasus tersebut Praperadilan, saat ini masyarakat sudah tidak asing lagi bahkan Praperadilan seolah-olah menjadi jalan alternatif bagi sesorang yang telah ditetapkan sebagai tersangka, terutama tersangka korupsi.

Gejala ini muncul setelah kemenangan Komjen Budi Gunawan (BG) dalam sidang praperadilan di Pengadilan Negeri Jakarta Selatan yang di pimpin oleh hakim tunggal Sarpin Rizaldi.Hal ini, berdampak pada penegakan hukum, 
khususnya pemberantasan korupsi. Pasca keputusan hakim Sarpin Rizaldi yang menyatakan bahwa status tersangka Komjen Budi Gunawan (BG) tidak sah sesuai dengan ketentuan undang-undang. Keputusan Sarpin menuai pro dan kontra bagi penegakan hukum di Indonesia. Bagi yang pro, ini merupakan sebuah terobosan hukum, dengan alasan seseorang yang telah ditetapkan sebagai tersangka masih bisa mengajukan upaya hukum melalui praperadilan dengan dalih untuk mencari keadilan. Sedangkan yang kontra, keputusan Sarpin merupakan kemunduran hukum, karena dampaknya adalah semua penyandang status tersangka bisa berbondong-bondong mengajukan kasusnya ke praperadilan, korupsi pun akan semakin merajalela, hakim Sarpin dianggap melampaui kewenangannya. Keputusan Hakim Sarpin bisa dibilang sejarah baru hukum di Indonesia, karena sebelumnya kasus tersangka yang mengajukan praperadilan selalu ditolak.

Kemenangan Komjen Budi Gunawan (BG). Dijadikan inspirasi sekaligus merupakan angin segar bagi pelaku kasus korupsi. Hal ini kemudian menjadi tren, yang disebut "Sapin Effect". Menggejalanya Sapin Effect sudah mulai terjadi, dengan banyaknya tersangka yang mengajukan gugatan praperadilan. Diantaranya, Mantan Menteri Agama Suryadharma Ali (SDA) yang ditetapkan sebagai tersangka oleh KPK. Kemudian, tersangka kasus suap pengelolaan migas Ketua Dewan Perwakilan Rakyat Daerah Bangkalan Fuad Amin, tersangka kasus korupsi dana pendidikan Bupati Sabu Raijua Marthen Dira Tome dan pedagang sapi di Banyumas Jawa Tengah, Mukti Ali juga mempraperadilankan Polres Banyumas karena dirinya ditetapkan sebagai tersangka kasus korupsi bantuan sosial (Bansos), nantinya ada ratusan hingga ribuan tersangka lainnya yang ditetapkan tersangka oleh instansi penegak hukum Polri dan Kejaksaan, juga akan melakukan upaya serupa.

Keputusan di Praperadilan Pengadilan Negeri Jakarta Selatan dalam kasus Budi Gunawan melawan Komisi Pemberantan Korupsi selain 
menimbulkan pro dan kontra juga menjadi perhatian bagi Komisi Yudisial (KY) sebagai lembaga pengawas berhak memeriksa dan memproses hakim-hakim yang dianggap kontroversial. Keputusan hakim yang bermasalah akan mengakibatkan ketidak adilan, hal ini perlu dicegah. Sebagai contoh saat ini adalah keputusan hakim Sarpin yang menuai kontroversi.KY harus menelusuri apakah hakim yang memutus sebuah kasus melakukan pelanggaran kode etik atau tidak.Sebab, jika melihat putusan yang terjadi, maka diduga yang dilakukan hakim bisa terkategori pengabaian hukum acara yang dilarang oleh prinsip disiplin tinggi dan profesional. ${ }^{1}$

Tugas hakim selain menerapkan hukum, membentuk hukum dan menemukan hukum, juga hakim harus menggali hukum yang ada dan keberadaanya di dalam masyarakat sebagai dasar pertimbangan ketika memutuskan suatu perkara, karena hukum sangat dipengaruhi faktor-faktor diluar hukum, seperti faktor politik, ekonomi, sosial, budaya dan lain sebagainya. ${ }^{2}$ Hal ini sesuai dengan pendapat Philippe Nonet dan Philip Selznick, menemukan tiga tipe hukum. Pembedaan tipologi ini berdasarkan pada pengakuan bahwa hukum dirumuskan oleh hubungannya dengan kekuasaan politik (recognition that law is defined by its relationship to political power"). Jadi tipologi hukum ini didasarkan pada bagaimana pandangan kekuasaan politik terhadap hukum. Tipologi hukum menurut Nonet dan Selznick, yaitu:

a. Hukum represif, yang ditandai dengan adaptasi yang pasif dan oportunistik saja dari institusi-institusi hukum terhadap lingkungan sosial dan politik. Karakteristik hukum represif adalah bahwa hukum disubordinasikan di bawah kekuasaan politik (law is subordinated to power politics). Dalam tipe ini

\footnotetext{
${ }^{1}$ Mukharom, Jateng Pos, Kolom OPINI, "Sarpin Efect" Mulai Menggejala. Terbit hari Senin, Tanggal 02 Maret2015, hlm.13

${ }^{2}$ Achmad Irwan Hamzani The Responsive Law Thinking Atmosphere: From the United States to Indonesia, International Journal of Advanced Science and Technology, Tahun 2020, Volume 29 (4), hlm, 514 .
} 
hukum merupakan peayan dari kekuasaan represif dan merupakan hukum yang sarat dengan sanksi.

b. Hukum otonom, yang kegiatan atau perhatian utamanya adalah bagaimana menjaga integritas institusional hukum. Dalam hukum otonom, hukum "independen" dari politik dan berusaha menahan diri dari kekuasaan politik. Pengertian ini dikenal sebagai rule of law. Pengadilan merupakan lembaga yang terpisah dari wilayah politik. Pemerintah sendiri terikat pada peraturanperaturan hukum.

c. Hukum responsif adalah hukum sebagai fasilitator respons terhadap kebutuhan dan aspirasi sosial (law is a facilitator of response to social needs and aspirations) di mana hukum itu harus mencari keadilan substantif (substantive justice). Dalam hukum responsif, tatanan hukum dinegosiasikan. Karakteristik hukum responsif adalah mencari nilai-nilai tersirat yang terdapat dalam peraturan dan kebijakan. ${ }^{3}$

Salah satu putusan yang dianggap kontroversial adalah Putusan No. 04/Pid.Prap/2015/PN.Jaksel tanggal 16 Februari 2015 yang diajukan oleh pemohon Kom.Jend. Polisi Drs. Gunawan, SH. M.Si. melawan Komisi Pemberantasan Korupsi (KPK) yang telah menetapkan Pemohon sebagai tersangka tindak pidana korupsi, karena secara mengejutkan Bapak Sarpin, SH. Yang menjadi Hakim Tunggal dalam perkara praperadilan tersebut mengabulkan gugatan praperadilan yang diajukan Pemohon dan mengalahkan KPK dan dalam salah satu amar putusannya menyatakan bahwa Surat Perintah Penyidikan Nomor: Sarpin.Dik-03/01/2015 tanggal 12 Januari 2015 yang telah menetapkan Pemohon sebagai tersangka tindak pidana korupsi adalah tidak sah dan tidak berdasarkan hukum dan oleh karenanya penetapan tersangka tidak mempunyai

\footnotetext{
3Philipe Nonet \& Philip Selznick, Hukum Reponsif. Pilihan di Masa Transisi, terjemahan Rafael Edy Bosco dari LawE Society in Transition: Toward Responsive Law, Jakarta: Huma, 2003, hlm. 3
} 
kekuatan mengikat, dan juga sekaligus menyatakan penyidikan yang dilakukan oleh termohon tidak sah dan tidak mempunyai kekuatan hukum mengikat.

Putusan tersebut telah menimbulkan kontroversi yang luar biasa besar bahkan sampai menimbulkan gelombang protes dari banyak ahli hukum serta memancing Komisi Yudisial (KY) untuk menanggapi dan bahkan sampai melakukan pemeriksaan atas terjadinya pelanggaran etika perilaku hakim yang diduga dilakukan oleh hakim Sarpin. ${ }^{4}$ Keputusan hakim Sarpin dalam memutuskan tentunya berdasarkan aspek keadilan, kemanfaatan dan kepastian hukum, hal ini sesuai dengan teorinya Gustav Radbruch adalah seorang filosof hukum dan seorang legal scholar dari Jerman yang terkemuka yang mengajarkan konsep tiga ide unsur dasar hukum. Ketiga konsep dasar tersebut dikemukakannya pada era Perang Dunia II. Tujuan hukum yang dikemukakannya tersebut oleh berbagai pakar diidentikkan juga sebagai tujuan hukum Adapun tiga tujuan hukum tersebut adalah keadilan, kepastian, dan kemanfaatan.

Penegakan hukum merupakan salah satu persoalan yang serius bagi bangsa Indonesia.Penegakan hukum sebagai usaha semua kekuatan bangsa, menjadi kewajiban kolektif semua komponen bangsa (dan ini sekaligus merupakan ralat bahwa hukum hanya boleh ditegakan oleh golongan-golongan tertentu saja).Hukum akan selalu berkembang seiring perkembangan zaman, kasus-kasus pun sekarang sangat beragam dan kompleks, oleh karena itu, perlu rancangan hukum yang ke kinian dalam mengatasi permasalahan-permasalahan yang muncul kini dan akan datang. Dalam RUU KUHP yang baru telah pula dimuat perluasan kewenangan praperadilan tidak hanya tentang berwenangnya memeriksa keabsahan penetapan tersangka, sah tidaknya penyidikan dan penuntutan, namun juga berwenang memeriksa tentang kerugian apa pun yang

${ }^{4}$ Maqadir Ismail, SF. Marbun, Mohammad Ikhsan, Himpunan Putusan Tentang Praperadilan, Yogyakarta: FH UII Press, 2017, hlm.6 
diderita oleh tersangka atau pihak yang berkepentingan yang ditimbulkan oleh tindakan penyidik yang sah. RUU KUHP yang nantinya disahkan menjadi KUHP buatan Indonesia memuat berbagai aturan yang disesuaikan dengan kondisi bangsa Indonesia.

\section{B. Rumusan Masalah}

1. Bagaimana dasar hukum yang digunakan Hakim dalam memutus perkara No. 04/Pid. Prap/2015/PN. Jaksel dalam sidang praperadilan?

2. Bagaimana kesesuaian Putusan Praperadilan No. 04/Pid. Prap/2015/PN. Jaksel dengan nilai dasar hukum yaitu keadilan, kepastian hukum dan kemanfaatan?

\section{Metode Penelitian}

\section{Metode Pendekatan}

Masalah pokok dalam penelitian ini adalah Analisis Normatif Terhadap Putusan Praperadilan No. 04/Pid.Prap/2015/PN.Jkt-Sel. Antara Komjen Budi Gunawan Melawan Komisi Pemberantasan Korupsi (KPK) Dipandang dari Sudut Kemanfaatan, Kepastian Hukum dan Keadilan.Berkaitan dengan hal tersebut, maka pendekatan yang digunakan dalam penelitian ini adalah pendekatan yang bersifat normatif. Penelitian hukum normatif yaitu memandang hukum bukan saja sebagai seperangkat kaidah yang normatif atau apa yang menjadi teks undang-undang (law in the book), akan tetapi juga melihat bagaimana hukum berinteraksi dengan masyarakat (law in action). Atau dengan kata lain untuk mengetahui terjadi gap (kesenjangan) antara kenyataan(das sain) dengan seharusnya (das sollen) dan bagaimana cara mengatasi suatu kesulitan. ${ }^{5}$

Alasan digunakan pendekatan ini dikarenakan penelitian yang diteliti berkaitan dengan Putusan Praperadilan No. 04/Pid.Prap/2015/PN.Jkt-Sel.

\footnotetext{
5Bustanudin Agus, Pengembangan Ilmu-Ilmu Sosial Studi Bidang Antara Pandangan Ilmiah Dan Ajaran Islam, Jakarta: Gema Insani, 1999, hlm. 71.
} 
Antara Komjen Budi Gunawan Melawan Komisi Pemberantasan Korupsi (KPK) Dipandang dari Sudut Kemanfaatan, Kepastian Hukum dan Keadilan.

\section{Sumber Data}

Dalam suatu penelitian umumnya dibedakan antara data yang diperoleh secara langsung dari masyarakat dan bahan-bahan pustaka.Sumber data yang langsung didapat dari masyarakat disebut dengan data primer sedangkan sumber data yang berasal dari bahan-bahan kepustakaan lazimnya dinamakna data sekunder. ${ }^{6}$ Namun penelitian ini menitikberatkan pada data sekunder, sedangkan data primer lebih bersifat penunjang atau membantu memperkuat data-data sekunder. Adapun data sekunder yang diteliti sebagai berikut :

1) Bahan hukum primer yaitu bahan hukum yang mengikat, meliputi :

a. Putusan Praperadilan No. 04/Pid. Prap/2015/PN. Jkt-Sel. Antara Komjen

Budi Gunawan selaku Pemohon Melawan Komisi Pemberantasan Korupsi (KPK) sebagai Termohon.

b. Sumber-sumber hukum mengenai praperadilan, serta peraturan perundang-undangan lain yang berhubungan dengan penelitian diatas.

c. Buku-buku yang membahas tentang praperadilan.

2) Bahan hukum sekunder meliputi :

a. Tulisan-tulisan atau pendapat para pakar hukum mengenai praperadilan.

b. Tulisan-tulisan atau pendapat para pakar hukum mengenaipenegakan hukum.

c. Bahan hukum tersier yang memberikan penjelasan lebih mendalam mengenai bahan hukum primer maupun bahan hukum sekunder antara

'Soerjono Soekanto dan Sri Marmudji, Penelitian Hukum Normatif Suatu Tinjauan Singkat, Jakarta: PT Radja Grafindo Persada, 2004, hlm.21. 
lain : Ensiklopedia Indonesia, Kamus hokum, Kamus bahasa InggrisIndonesia, Berbagi majalah maupun jurnal hukum

Namun demikian masih diperlukannya data primer untuk melengkapi sajian kajian diatas. Adapun data primer meliputi :

a. Wawancara dengan para hakim baik ditingkat pertama, untuk mengetahui sejauh mana persiapan para hakim dalam menyongsong siding praperadilan.

b. Wawancara dengan para pakar hukum mengenai praperadilan.

\section{Teknik Pengumpulan Data}

Semua data yang terkumpul baik itu data sekunder maupun data primer secara garis besar dianalisis dengan menggunakan metode deskriptif. Sesuai dengan metode pendekatan yang digunakan, maka dalam penelitian ini analisis yang digunakan adalah sebagai berikut :

a. Tahap pertama, mendasarkan pada pendekatan doktrinal. Pada tahap ini terutama peneliti melakukan inventarisasi. Terhadap Putusan Praperadilan No. 04/Pid. Prap/2015/PN. Jkt-Sel. Antara Komjen Budi Gunawan Melawan Komisi Pemberantasan Korupsi (KPK) dalam memeriksa, memutuskan dan menyelesaikan suatu perkara praperadilan. Dalam hal ini dilakukan pengumpulan terhadap semua asas-asas atau kaidah-kaidah yang terkait dengan permasalahannya, untuk kemudian diorganisisr kedalam suatu sisitem yang komprehensif, setelah sebelumnya dilakukan koleksi terhadap seluruh asas dan kaidah-kaidah yang telah terkumpul tersebut.

b. Tahap kedua, mendasarkan pada penelitian non doktrinal. Analisisi dilaksanakan dengan menggunakan metode analisis deskriptif.

\section{Analisis Data}

Berdasarkan rumusan masalah dan tujuan penelitian, maka analisa data dilakukan secara kualitatif. Untuk menunjang hal tersebut diperlukan 
kajian empirik, sehingga analisa data lebih bersifat komparatif. Metode yang digunakan adalah metode induktif, kemudian mengkonstruksikan data/fakta.

\section{Pembahasan}

\section{Dasar Hukum Hakim Praperadilan Memutuskan Perkaranya.}

Penegak hukum di Indonesia memiliki peran penting dalam proses mewujudkan keadilan bagi mereka yang berperkara di pengadilan, tidak hanya mendapatkan keadilan prosedural akan tetapi keadilan substansial, di mana hakim memiliki kewenangan untuk memutuskan dan menetapkan perkara yang masuk ke pengadilan serta menjadi tanggungjawab sang pengadil yaitu hakim.

Praperadilan adalah satu cerminan pelaksanaan dari asas praduga tidak bersalah (presumption of innocent), dimana tiap orang yang diajukan sebagai tersangka/terdakwa telah melalui proses awal yang wajar dan mendapat perlindungan harkat dan martabat manusianya. ${ }^{7}$

Lahirnya lembaga Praperadilan adalah terinspirasi oleh prinsipprinsip yang bersumber dari adanya hak Habeas Corpus dalam sistem peradilan Anglo Saxon, yang memberikan jaminan fundamental terhadap hak asasi manusia khususnya hak kemerdekaan. Habeas Corpus Act memberikan hak pada seseorang melalui suatu surat perintah pengadilan menuntut pejabat yang melaksanakan hukum pidana formil tersebut agar tidak melanggar hukum (ilegal) atau tegasnya melaksanakan hukum pidana formal tersebut benar-benar sah sesuai dengan ketentuan hukum yang berlaku. Hal ini untuk menjamin bahwa perampasan ataupun pembatasan kemerdekaan terhadap seseorang tersangka atau terdakwa itu benar-benar

\footnotetext{
${ }^{7}$ Wahyu Januar, Studi Komparatif Hukum Wewenang Dan Fungsi Praperadilan Menurut Hukum Acara Pidana Indonesia Dengan Sistem Habeas Corpus Di Amerika Serikat, (Surakarta: FH. Universitas Sebelas Maret, 2011), hlm. 33.
} 
telah memenuhi ketentuan-ketentuan hukum yang berlaku maupun jaminan hak-hak asasi manusia.

Keberadaan lembaga Praperadilan, sebagaimana diatur dalam Bab X Bagian Kesatu KUHAP dan Bab XII Bagian Kesatu KUHAP Jo. Bab VIII, Undang-Undang Nomor 30 Tahun 2002 tentang Komisi Pemberantasan Tindak Pidana Korupsi (Selanjutnya disebut UUKPK), secara jelas dan tegas diimaksudkan sebagai sarana kontrol atau pengawasan horizontal untuk menguji keabsahan penggunaan wewenang oleh aparat penegak hukum (Penyelidik/Penyidik maupun Penuntut Umum), sebagai suatu koreksi terhadap penggunaan wewenang apabila dilaksanakan secara sewenangwenang dengan maksud/tujuan lain di luar dari yang ditentukan secara tegas dalam KUHAP, guna menjamin perlindungan terhadap hak asasi setiap orang.

Lembaga Praperadilan sebagaimana diaitur dalam Pasal 77 s/d 83 KUHAP adalah suatu lembaga yang berfungsi untuk menguji apakah tindakan/upaya paksa yang dilakukan oleh penyidik/penuntut umum sudah sesuai dengan undang-undang dan tindakan tersebut telah dilengkapi administrasi penyidikan secara cermat atau tidak, karena pada dasarnya tuntutan Praperadilan menyangkut sah tidaknya tindakan penyidik atau penuntut umum di dalam melakukan penyidikan atau penuntutan.Tujuan Praperadilan seperti yang tersirat dalam penjelasan Pasal 80 KUHAP adalah untuk menegakan hukum, keadilan, kebenaran melalui sarana pengawasan horizontal, sehingga esensi dari Praperadilan adalah untuk mengawasi tindakan upaya paksa yang dilakukan oleh penyidik penuntut umum terhadap tersangka, benar-benar dilaksanakan sesuai ketentuan undangundang, dilakukan secara profesional dan bukan tindakan yang bertentangan dengan hukum sebagaimana diatur dalam KUHAP atau perundangundangan lainnya. 
Lembaga Praperadilan sebagai upaya pengawasan penggunaan wewenang guna menjamin perlindungan Hak Asasi Manusia, telah dituangkan secara tegas dalam Konsiderans Menimbang huruf (a) dan (c) KUHAP dengan sendirinya menjadi spirit atau ruh atau jiwanya KUHAP yang berbunyi:

a. "bahwa Negara Republik Indonesia adalah negara hukum berdasarkan Pancasila dan Undang-Undang Dasar 1945 yang menjunjung tinggi hak asasi manusia serta yang menjamin segala warga negara bersamaan kedudukannya di dalam hukum dan pemerintahan dan wajib menjunjung hukum dan pemerintahan itu dengan tidak ada kecualinya".

b. “bahwa pembangunan nasional yang demikian itu dibidang hukum acara pidana adalah agar masyarakat menghayati hak dan kewajibannya dan untuk meningkatkan pembinaan sikap para pelaksana penegak hukum sesuai dengan fungsi dan wewenang masing-masing kearah tegaknya hukum, keadilan dan perlindungan terhadap harkat dan martabat manusia, ketertiban serta kepastian hukum demi terselenggaranya negara hukum sesuai dengan Undang-Undang Dasar 1945".

Pasal 95 menyebutkan bahwa:

(1)Tersangka, terdakwa atau terpidana berhak menuntut ganti kerugian karena ditangkap, ditahan, dituntut, dan diadili atau dikenakan tindakan lain, tanpa alasan yang berdasarkan undang-undang atau karena kekeliruan mengenai orangnya atau hukum yang diterapkan.

(2)Tuntutan ganti kerugian oleh tersangka atau ahli warisnya atas penangkapan dan penahanan serta tindakan lain tanpa alasan yang berdasarkan undang-undang atau karena kekeliruan mengenai orang atau hukum yang diterapkan sebagaiman dimaksud dalam ayat (1) yang perkaranya tidak diajukan ke pengadilan negeri, diputus disidang Praperadilan sebagaimana dimaksud dalam Pasal 77. 
Bahwa permohonan yang dapat diajukan dalam pemeriksaan Praperadilan selain daripada persoalan sah atau tidaknya penangkapan, penahanan, penghentian penyidikan atau penghentian penuntutan maupun ganti kerugian dan/atau rehabilitasi bagi seseorang yang perkara pidananya dihentikan pada tingkat penyiidikan atau penuntutan (Pasal 77 KUHAP).

Pasal 95 ayat (1) dan (2) pada pokoknya merupakan tindakan penyidik atau penuntut umum dalam rangka menjalankan wewenangnya yang dilakukan tanpa alasan hukum, sehingga melanggar hak asasi atau harkat martabat kemanusiaan atau merugikan seseorang, in casu adalah permohonan. Oleh karena itu tindakan lain yang dilakukan adalah mengajukan ke Praperadilan.

Salah satu kasus berkenaan dengan praperadilan di Indonesia yaitu kasus Komisaris Jenderal Polisi Budi Gunawan (selanjutnya disebut Budi Gunawan) yang mengajukan Praperadilan terhadap penetapan status tersangka atas dugaan korupsi yang di dikeluarkan Komisi Pemberantasan Korupsi (KPK). Maqdir Ismail sebagai kuasa hukum Budi Gunawan memberikan pernyataan bahwa bahwa penetapan tersangka diatas dianggap tidak sesuai dengan prosedur sehingga penetapan tersangka diangggap cacat secara yuridis. ${ }^{8}$ Status tersangka yang dijadikan sebagai objek dalam Praperadilan menjadi masalah baru untuk masyarakat Indonesia, mengingat bahwa objek Praperadilan dalam Pasal 1 angka 10 Kitab Undang-Undang Hukum Acara Pidana hanya mengenai penangkapan atau penahanan, penghentian penyidikan atau penghentian penuntutan, dan ganti kerugian atau rehabilitas. Kasus diatas semakin menguatkan paradigma masyarakat terhadap penegakan hukum di Indonesia bahwa hukum tumpul ke atas dan tajam ke bawah.

${ }^{8}$ Fathiyah Wardah, Sidang Praperadilan Komjen Budi Gunawan Digelar,http://www.voaindonesia.com 
Pada putusan perkara Praperadilan Budi Gunawan (Pemohon), terdapat pertimbangan hukum yang berbunyi, "Menimbang, bahwa dari rumusan pengertian Pasal 1 angka 10 jo. Pasal 82 ayat (1) dan ayat (2) tersebut dapat diketahui dengan jelas, bahwa sah atau tidaknya penetapan Pemohon tidak termasuk objek Praperadilan, karena hal itu tidak diatur". ${ }^{9}$ Selanjutnya, bersambung ke pertimbangan putusan halaman 223 yang berbunyi, "Menimbang, bahwa demikian pula halnya dengan sengaja ketentuan peraturan perundang-undangan pidana khusus yang berlaku sebagai hukum positif di Indonesia juga tidak ditemukan aturan yang mengatur jika pengujian tentang sah atau tidaknya Penetapan Pemohon menjadi objek Praperadilan.

Hakim tunggal sebagai hakim senior seharusnya dapat menghentikan pertimbangan hukum di situ saja dan menolak permohonan Praperadilan yang diajukan Pemohon, dengan pertimbangan bahwa, "tidak ditemukan atau jelasnya tidak ada aturan tentang sah atau tidaknya penetapan Pemohon dan karenanya tidak termasuk objek Praperadilan seperti diatur dalam Pasal 1 angka 10 jo. Pasal 77 jo. Pasal 82 ayat (1) dan ayat (2) KUHAP”. ${ }^{10}$

Pertimbangan hukum yang dilanjutkan dengan dalil-dalil seperti yang dikemukakan dalam pertimbangan selanjutnya mengisyaratkan hakim tunggal memaksakan diri untuk mencari dalil yang seolah-olah sengaja direncanakan terlebih dahulu untuk sampai pada amar putusan mengabulkan permohonan Pemohon. Seharusnya seorang hakim berhati-hati membuat pertimbangan hukum dalam suatu putusan, sebab hakim tidak boleh menunjukan keberpihakan. 'tidak berpihak' adalah landasan penting

\footnotetext{
${ }^{9}$ Putusan Nomor 04/Pid.Prap/2015/ PN.Jkt.Sel, Pengadilan Negeri Jakarta selatan,16 Februari 2015 (Putusan). hlm.222

${ }^{10}$ Komariah Emong Sapardjaja, Kajian dan Catatan Hukum Atas Putusan Praperadilan Nomor 04/Pid.Prap/2015/PN.Jkt.Sel Tertanggal 16 Februari 2015 Pada Kasus Budi Gunawan:Sebuah Analisis Krisis, Padjadjaran Jurnal Ilmu Hukum Volume 2 Nomor 1 Tahun 2015, hlm. 16
} 
bagi hakim dalam menjalankan proses peradilan pidana, disamping tetap selalu berada dalam koridor hukum acara yang benar. ${ }^{11}$

Asas legalitas dalam hukum acara pidana telah dinyakan secara tegas, yang disebut dalam konsiderans KUHAP huruf a, yang berbunyi, "bahwa negara Republik Indonesia adalah negara hukum yang berdasarkan Pancasila dan Undang-Undang Dasar 1945 (UUD 1945) yang menjunjung tinggi hak asasi manusia serta yang menjamin segala warga negara bersamaan kedudukannya di dalam hukum dan pemerintahan dan wajib menjunjung tinggi hukum dan pemerintahan itu dengan tidak ada kecualinya". ${ }^{12}$ Berdasarkan konsiderans ini, pelaksanaan KUHAP harus bersumber pada titik tolak the rule of law, semua tindakan penegakan hukum harus berdasarkan ketentuan hukum dan undang-undang. Maka jelaslah KUHAP sebagai hukum acara pidana adalah undang-undang yang asas hukumnya berlandaskan asas legalitas. ${ }^{13}$

KUHAP juga mencantumkan perlunya asas legalitas dalam Bab II Pasal 2 dan Bab III Pasal 3. Khususnya dalam Pasal 3 ditetapkan. "Peradilan dilakukan menurut cara yang diatur dalam undang-undang ini". Meskipun padanan ketentuan Pasal 3 salah susun, tetap saja ketentuan ini merupakan padanan dari Pasal 1 Strafvordering Belanda, yang mengatur mengenai asas legalitas dalam hukum acara pidana, sebagaimana berbunyi, "Strafvordering heeft aleen plaats op de wijze bij wet voorzien" atau hukum acara pidana dijalankan hanya berdasarkan cara yang ditentukan oleh undang-undang. ${ }^{14}$

${ }^{11}$ G.J.M Corstens.Net Nederlandse srafprocesrecht, Arnhem:Gauda Quint/Dbrouwer en zoon,1993, hlm. 13

${ }^{12}$ Yahya Harahhap, Pembahasan Permasalahan dan Penerapan KUHAP, Jakarta: Sinar Grafika, 2014, hlm. 36

${ }^{13}$ Komariah Emong Sapardjaja, op.cit, hlm. 17

${ }^{14}$ Andi Hamzah, Hukum Acara Pidana Indonesia, Jakarta: Sinar Grafika, 2008, hlm. 11 
Dengan demikian adalah tidak benar hukum acara pidana tidak mengenal asas legalitas.

Formulasi yang relevan untuk dibahas dalam putusan praperadilan adalah Pasal 77 huruf a KUHAP. Dalam ketentuan huruf a tersebut disebutkan secara eksplisit adanya 4 (empat) tindakan yang dapat diperiksa atau diputuskan keabsahannya. Jadi, apabila hakim praperadilan hendak melakukan penafsiran yang memperluas makna (interpretasi ekstensif) terhadap kata "upaya paksa", hakim Praperadilan seharusnya hanya melakukan interpretasi perluasan makna terhadap kata "penangkapan" dan/atau "penahanan" saja. Penetapan tersangka tidak termasuk dalam klasifikasi yang sama dengan klasifikasi penangkapan dan/atau penahanan. Hal ini dikarenakan penangkapan dan/atau penahanan adalah proses awal sebelum seseorang dinyatakan sebagai tersangka. Penetapan sebagai tersangka tidak termasuk sebagai perluasan makna dari kata "penangkapan" dan/atau "penahanan" dan tentunya tidak dapat dikategorikan sebagai "upaya paksa" yang merupakan obyek pemeriksaan lembaga Praperadilan. Dengan perkataan lain, seorang penafsir tidak dapat menggunakan penafsiran ekstensif dari kata penangkapan dan/atau penahanan untuk kemudian sampai pada kesimpulan bahwa dari kedua kata itu bisa dimunculkan kata "penetapan tersangka".

Alasan-alasan hakim tunggal untuk melakukan penemuan hukum sebagaimana disebutkan dalam pertimbangan hukum adalah:

1. Dalam putusan disebutkan, " menimbang bahwa masalahnya sekarang adalah: karena hukumnya tidak mengatur, apakah hakim boleh menolak suatu perkara dengan alasan, pertimbangan bahwa 'hukum tidak mengatur' atau 'hukumnya tidak ada'.

2. Hakim tunggal juga mengutip Pasal 5 ayat (1) dan Pasal 10 ayat (1) Undang-Undang Nomor 48 Tahun 2009 tentang Kekuasaan Kehakiman. 
3. Selanjutnya bahwa larangan bagi hakim menolak untuk memeriksa, mengadili dan memutuskan suatu perkara dengan dalih atau alasan bahwa hukumnya tidak ada, tentunya melahirkan kewenangan yang diberikan kepada hakim untuk menetapkan hukum yang semula tidak ada menjadi ada atau yang semula tidak jelas menjadi jelas.

4. Pertimbangan yang berbunyi, Menimbang bahwa kewenangan hakim untuk menetapkan hukum yang semula hukumnya tidak ada menjadi ada, dilakukan dengan menggunakan metode penemuan hukum (rechts vinding) yang jika dikaji secara ilmiah (keilmuan) dan secara yuridis harus dapat dipertanggungjawabkan".

5. Selanjutnya disebutkan, "Menimbang bahwa kewenangan hakim untuk menetapkan hukum yang semula tidak ada menjadi ada, dilakukan dengan menggunakan dan menerapkan metode penafsiran (interpretasi). ${ }^{15}$

Mengingat objek Permohonan Praperadilan yang diajukan pemohon dalam perkara a quo adalah mengenai sah atau tidaknya penetapan tersangka, sementara Pasal 1 angka 10, Pasal 77 sampai Pasal 82, dan Pasal 95 sampa Pasal 97 KUHP secara limitatif telah mengatur hal-hal apa saja yyang menjadi wewenang Praperadilan yaitu mengenai keabsahan tindakan penyidik atau penuntut umum (penahanan, penangkapan, penghentian penyidikan, dan penghentian penuntutan), mengenai ganti kerugian atas penangkapan atau penahanan serta tindakan lain (pemasukan rumah, penggeledahan, dan penyitaan) tanpa alasan yang sah atau kekeliruan mengeni orang atau hukum yang diterapkan yang perkaranya tidak diajukan ke pengadilan negeri, maka langkah hakim Praperadilan melakukan rechtsvinding sudah tepat dan memang sudah seharusnya demikian, karena salah satu beberapa alasan perlunya melakukan penemuan hukum oleh hakim telah terpenuhi yaitu

${ }^{15 K o m a r i a h ~ E m o n g ~ S a p a r d j a j a, ~ o p . c i t . ~ h l m . ~} 18$ 
peraturan tidak ada, atau peraturannya ada tapi kurang jelas. Bahkan tanpa alasan-alasan tersebut pun, seorang hakim tetap dianggap melakukan penemuan hukum (dalam arti sempit) yaitu ketika ia menemukan kecocokan antara maksud atau bunyi peraturan perundang-undangan dengan kualifikasi peristiwa atau kasus konkritnya.

Dalam perkara a quo, hakim Praperadilan secara tegas menyatakan dalam pertimbangan hukumnya bahwa sah atau tidaknya penetapan tersangka tidak termasuk obyek Praperadilan, dengan alasan hal tersebut tidak diatur baik dalam KUHP khususnya Pasal 1 angka 10 jo. Pasal 77 jo. Pasal 82 ayat (1) jo. Pasal 95 ayat (1) dan ayat (2) maupun dalam peraturan perundang-undangan pidana khusus yang berlaku sebagai hukum positif di Indonesia. Atas alasan itu, penemuan hukum yang dilakukan oleh hakim Praperadilan dilakukan karena dalam peraturan perundang-undangan yang ada, baik KUHAP maupun undang-undang lain, tidak mengatur masalah keabsahan penetapan tersangka sebagai obyek Praperadilan. Di sini terlihat, hakim Praperadilan telah menempatkan dirinya bukan hanya sekedar corong undang-undang (qui pronoce les paroles de al loi) sebagaimana dikatakan Montesquieu, tetapi telah menerapkan hukum pidana sesuai dengan hukum yang hidup di dalam masyarakat.

Perkembangan masyarakat mampu melahirkan perkembangan dan penemuan hukum. Hal ini tentu saja menyangkal pendapat para sarjana di akhir abad ke 19 bahwa hukum merupakan satu kesatuan lengkap yang tertutup, di luar Undang-undang tidak ada hukum, dan hakim tak boleh menjalankan keadaan hukum yang tidak disebutkan dalam peraturan perundang-undangan.8 Namun pada kenyataannya sekarang, terjadi kesatuan pemahaman mengenai sistem hukum yang terbuka, yang diakibatkan oleh kemajuan masyarakat dan 
berdampak kepada cara berfikir mengenai hukum tersebut menjadi lebih dinamis. ${ }^{16}$

Konsekuensi dari hal tersebut adalah kewajiban dari seorang hakim untuk melakukan penemuan atas kekosongan hukum yang terjadi. Berdasarkan salah satu asas ilmu hukum yaitu ius curia novit, dimana hakim tidak boleh menolak perkara yang diberikan kepadanya dengan alasan tidak adanya peraturan hukum yang mengaturnya, oleh sebab itu jelaslah bahwa hakim harus memenuhi kebutuhan akan kekosongan hukum tersebut menurut sistem hukum yang berlaku dan ditetapkan.

Dengan dikeluarkannya putusan Hakim Sarpin, bisa diikuti oleh hakim-hakim lain sebagai yurisprudensi.Tentunya hal tersebut memiliki perubahan antara sebelum dan sesudah putusan tersebut keluar.Hal tersebut terlihat dari banyaknya permohonan praperadilan yang masuk ke pengadilan dengan permohonan mengenai tidak sahnya penetapan status tersangka. Hal tersebut wajar terjadi sebab akan membuka celah bagi setiap orang yang ditetapkan sebagai tersangka untuk melakukan upaya hukum-upaya hukum yang tersedia, termasuk praperadilan, guna mencari keadilan maupun sebagai jalan agar terlepas dari tuntutan hukum tanpa harus masuk ke dalam proses Peradilan. Ditambah lagi, tidak terjadi kesatuan pemahaman pada setiap hakim untuk menjatuhkan putusan serupa putusan Hakim Sarpin.Hal tersebut tentu saja bukan perwujudan daripada tujuan hukum yaitu untuk mencapai keadilan dan kepastian hukum. Oleh sebab itu penulis tertarik untuk mengangkat judul skripsi, "Implikasi Hukum Putusan Praperadilan No. 04/Pid.Prap/2015/PN.Jkt.Sel.dalam Kasus Praperadilan Budi Gunawan Sebagai Yurisprudensi Terhadap Proses Praperadilan dalam Sistem Hukum Pidana Indonesia."

${ }_{16}$ C.S.T. Kansil, 2011, Pengantar Ilmu Hukum Indonesia, Jakarta, Rineka Cipta,hlm.76 
2. Putusan Praperadilan No. 04/Pid. Prap/2015/PN. Jaksel Ditinjau Dari Nilai DasarHukum Yaitu Keadilan, Kepastian Hukum Dan Kemanfaatan.

Penegakan hukum di Indonesia masih dihambat berbagai permasalahan yang menjauhkan hukum dari tujuan utamanya untuk memelihara keadilan, kepastian hukum dan kemanfaatan bagi masyarakat. ${ }^{17}$ Permasalahan dalam praktik penegakan hukum timbul saat terjadi kesenjangan antara prakteknya (das sein) dengan seharusnya (das sollen). ${ }^{18}$ Dewasa ini banyak sekali kasus bermunculan, baik kasus biasa (konvensional) ataupun kasus besar (extra ordinary crime).

Indonesia adalah negara yang berdasarkan atas hukum (Rechtsstaat). Ini berarti bahwa Indonesia adalah negara yang berdasarkan hukum (Rechtsstaat), tidak berdasarkan kekuasaan belaka (Machtsstaat). Negara yang berdasarkan hukum menuntut kepada negara, pemerintah, lembaga negara yang lain, bahkan semua warga negara Indonesia, dalam melaksanakan tindakan apa pun harus dilandasi oleh hukum atau dapat dipertanggungjawaban di muka umum.

Pengertian negara hukum menurut UUD 1945 adalah negara hukum dalam arti luas, yaitu negara hukum dalam arti materiil. Negara buakan saja melindungi segenap bangsa Indonesia dan seluruh tanah tumpah darah Indonesia, melainkan juga harus memajukan kesejahteraan umum dan mencerdaskan kehidupan bangsa. ${ }^{19}$

Hukumacara pidana memberikan kepastian hukum kepada individu dalam masyarakat, karena sesungguhnya hukum acara pidana menjamin

\footnotetext{
${ }^{17}$ Eman Suparman, Membumikan Tekad Menuju Peradilan Bersih, Komisi Yudisial, Jakarta Pusat, 2011, hlm 3

${ }^{18}$ Das sein adalah keadaan empirik, atau realita, sedangkan Das Sollen adalah keadaan ideal atau dengan apa yangdiharapkan. Bahder Johan, Metode Penelitian Hukum, Mandar Maju, Bandung, 2008, hlm 77

${ }^{19}$ Yulies Tiena Masriani, Pengantar Hukum Indonesia, Jakarta: Sinar Grafika, 2013, hlm. 38
} 
berlakunya hukum pidana secara tertib melalui undang-undang. Oleh karenanya, tidak dapat pula pembentuk atau pembuat undang-undang menciptakan suatu peraturan yang ragu-ragu, tidak jelas, atau memberikan peluang penafsiran yang terlampau luas. Terlebih lagi bagi seorang hakim, walaupun di negara modern ini tidak lagi menjadi corong undang-undang, tetapi hukum acara pidana membatasi secara ketat keinginan-keinginan hakim untuk memperluas dan memaksakan diri melawan undang-undang hukum acara pidana dengan dalih apapun. Oleh karena itu, penemuan hukum di bidang hukum acara pidana menjadi amat sangat terbatas, jauh lebih terbatas dibandingkan dengan hukum pidana itu sendiri.

Kewenangan hakim dalam menetapkan hukum yang semula tidak ada, dalam pertimbangan hukum a quo adalah melahirkan kewenangan kepada hakim untuk menetapkan hukum yang semula tidak ada menjadi ada, menetapkan hukum, yang kemudian menjadi hukum positif dan berlaku sebagai undang-undang, bukanlah pekerjaan seorang hakim. Sebagaimana diattur dalam UUD 1945 menetapkan suatu perbuatan atau keadaan menjadi perbuatan hukum, hanyalah kewenangan badan pembuat undang-undang, yang dalam sistem ketatanegaraan di Indonesia dilakukan oleh Dewan Perwakilan Rakyat (DPR) bersama-sama dengan Presiden.

Pembagian kekuasaan dalam suatu negara hukum seperti yang diamanatkan dalam UUD 1945 dengan sangat jelas merinci kekuasaan legislatif, kekuasaan yudikatif, dan kekuasaan eksekutif. Kewenangan tiaptiap lembaga yang memegang kekuasaan tersebut juga sangat jelas. Montesqieu, melahirkan prinsip Trias Politica yang telah mengakhiri kekuasaan mutlak raja-raja Prancis. Hampir semua negara modern yang ada di dunia saat ini memegang prinsip Trias Politica karena tidak ada suatu negara pun yang masih menghendaki kekuasaan tirani dalam pemerintahannya. 
Di Indonesia tidak dikenal pemisahan seperti yang dikemukakan oleh Montesquieu itu. Hal ini dapat dilihat dalam hal:

a. Kekuasaan perundangan tidak hanya dilaksanakan oleh DPR, tetapi bersama-sama Presiden sebagai penguasa eksekutif.

b. Kekuasaan peradilan tidak hanya dilaksanakan oleh pejabat pengadilan, tetapi juga dijalankan oleh pejabat yang bukan pejabat pengadilan. Misalnya BPSP (Badan Penyelesaian Sengketa Pajak) dalam bidang perpajakan. ${ }^{20}$

Penemuan hukum (rechtsvinding) adalah proses mencari norma hukum yang baik dalam peraturan peundang-undangan maupun norma hukum yang hidup dalam masyarakat. Dalam kondisi undang-undang tidak jelas atau tidak lengkap mengatur, hakim sebagai pelaksana undang-undang wajib menggali, mengikuti, dan memahami nilai-nilai hukum dan rasa keadilan yang hidup dalam masyarakat. Pada hakekatnya, penemuan hukum oleh hakim merupakan tindakan untuk mensiasati kesenjangan yang terjadi antara hukum yang di atas kertas (law in the books) dan hukum yang hidup dalam kenyataan atau yang hidup dalam masyarakat (law in action, the living law). Melihat begitu pentingnya peranan hakim dalam melakukan penemuan hukum, Pasal 5 ayat (1) UU No. 48 Tahun 2009 tentang Kekuasaan Kehakiman menjadikan peran hakim tersebut sebagai suatu kewajiban seorang hakim dengan menyatakan, "Hakim dan hakim konstitusi wajib menggali, mengikuti, dan memahami nilai-nilai hukum dan rasa keadilan yang hidup dalam masyarakat". 21

\footnotetext{
${ }^{20} \mathrm{Ibid}, \mathrm{hlm} .38$

${ }^{21}$ Fety Rahmah Wardani, Publikasi Ilmiah, Analisis terhadap Putusan Praperadilan oleh Hakiim dalam Penetapan Tersangka ditinjau dari Hukum Acara Pidana Indonesia. (Studi Kasus Putusan Praperadilan terhadap Penetapan Tersangka Komjen Pol Budi Gunawan di Pengadilan Negeri Jakarta Pusat), hlm. 10
} 
Penemuan hukum oleh hakim sesungguhnya merupakan salah satu instrumen yang digunakan oleh hakim untuk tidak hanya sekedar menerapkan maksud dan bunyi peraturan perundang-undangan dengan kualifikasi peristiwa atau kasus konkritnya (penemuan hukum dalam arti sempit), tapi juga untuk mengisi kekosongan hukum (rechtvacuum) atau menafsirkan suatu kaidah peraturan perundang-undangan yang tidak atau kurang jelas yakni dengan cara memperluas makna suatu ketentuan undangundang (penemuan hukum dalam arti luas), melalui dua metode penemuan hukum, yaitu metode penafsiran hukum dan metode konstruksi hukum. Metode penafsiran hukum adalah penafsiran perkataan dalam undangundang tetapi tetap berpegang pada kata-kata/bunyi peraturannya, sedangkan metode konstruksi hukum adalah penalaran logis untuk mengembangkan suatu ketentuan dalam undang-undang yang tidak lagi berpegang pada kata-katanya, tetapi tetap harus memperhatikan hukum sebagai suatu sistem. Agar proses penemuan hukum oleh seorang hakim dapat menghasilkan putusan yang berkualitas yang pada ujungnya memenuhi rasa keadilan bagi masyarakat, maka kemampuan memilih metode penemuan hukum yang tepat dan jenis penemuan hukum mana dari kedua metode tersebut yang akan digunakan harus dikuasai secara baik oleh seorang hakim.

Sehubungan dengan perkara ini, penemuan hukum yang dilakukan oleh hakim dapat dibaca dari kedua metode hukum tersebut. Dalam konteks penafsiran, salah satu jenis penafsiran yang terkait dengan perkara a quo adalah penafsiran ekstensif. Melalui penafsiran ekstentif, hakim melakukan perluasan makna dari ketentuan khusus menjadi ketentuan umum sesuia dengan kaidah tata bahasanya. Disini hakim menafsirkan kaidah tata bahasa, karena maksud dantujuannya kurang jelas atau terlalu abstrak agar menjadi jelas dan konkrit, perlu diperluas maknanya. Misalnya, kata " pencurian 
barang" dalam Pasal 362 KUHP, diperluas esensi maknanya terhadap "aliran listrik" sebagai benda yang tidak berwujud.hasil dari penafsiran ekstensif dalam kasus pencurian barang ini adalah barang diartikan luas oleh hakim meliputi juga aliran listrik, tetapi tidak menciptakan delik baru melainkan masih tetap pencurian. Berdasarkan esensi makna dan praktik penerapannya, penafsiran ekstentif dilakukan dengan memperluas makna kata atau kalimat yang terdapat dalam suatu peraturan perundang-undangan dengan menemukan padanan atau kecocokannya dengan kata atau kalimat yang lain tanpa mengubah atau mengganti substansi maksud dari ketentuan perundang-undangan yang ditafsirkan. Sementara untuk metode konstruksi hukum, terkait perkara a quo adalah argumentum a'contrario. Konstruksi hukum argumentum a'contrario adalah penalaran terhadap suatu ketentuan undang-undang pada peristiwa hukum tertentu, sehingga secara a'contrario atau sebaliknya ketentuan tersebut tidak boleh diberlakukan pada hal-hal atau kebalikannya (expressie unius est exclusio alterius, the mention of obe is the ezclusion of another).

Metode konstruksi digunakan ketika dalam penyelesaian peristiwa konkrit hakim dihadapkan pada kokosongan hukum. Dari beberapa metode penemuan hukum yang termasuk ke dalam metode konstruksi, metode "argumentum analogiam" atu sering disebut metode analogi merupakan metode yang cenderung dan sering digunakan. Terkait dengan metode ini, Prof Sudikno Mertokusumo menyatakan: kadang-kadang peraturan perundang-undangan terlalu sempit ruang lingkupnya. Dalam hal ini untuk dapat menerapkan undang-undang pada peristiwanya, hakim akan memperluasnya dengan metode berfikir analogi. Dengan analogi, maka peristiwa yang serupa, sejenis atau mirip dengan yang diatur dalam undangundang diperlakukan sama. 
Tindakan hakim tunggal Sarpin Rizaldi juga dapat diperkuat oleh bunyi Pasal 10 ayat (1) undang-undang yang sama, yang menentukan bahwa, "Pengadilan dilarang menolak untuk memeriksa, mengadili, dan memutus suatu perkara yang diajukan dengan dalih bahwa hukum tidak ada atau kurang jelas, melainkan wajib untuk memeriksa dan mengadilinya". Ketentuan Pasal 10 ayat (1) tersebut diatas mengandung arti bahwa “...hakim sebagai organ utama dalam suatu pengadilan dan sebagai pelaksana kekuasaan kehakiman, untuk menerima, memeriksa, mengadili suatu perkara da selanjutnya menjatuhkan putusan, sehingga dengan demikian wajib hukumnya bagi hakim untuk menemukan hukumnya dalam suatu perkara meskipun ketentuan hukumnya tidak jelas ataupun kurang jelas." 22

Dengan demikian, berdasarkan analisis terhadap logika hukum hakim praperadilan sebagaimana tersebut di atas, maka aspek keadilan dan kepastian hukum dari putusan perkara a quo adalah sebagai berikut:

1. Terkait aspek keadilan, dalam proses pemeriksaan perkara pidana, prosedur pemeriksaan perkara pidana melalui tahapan-tahapan pemeriksaan. Pada tahapan pertama dikenal sebagai keadilan prosedural (procedural justice). Pada bagian ini dituntut ditegakkannya asas-asas hukum. Bagian kedua adalah keadilan substansial (substantial justice) yang bergantung kepada keadilan yang pertama. Artinya jika prosedurnya yang adil yang diatur dalam hukum acara pidana atau hukum pidana formil sudah ditegakkan, merupakan prasyarat terwujudnya keadilan substansial yang diatur dalam hukum pidana materiil, sebaliknya prosedur yang tidak adil tidak dapat melahirkan keadilan substansial. ${ }^{23}$ Dalam perkara a quo, hakim praperadilan seolah-olah hendak mewujudkan keadilan substansial

\footnotetext{
${ }^{22}$ Ahmad Rifai, 2010, Penemuan Hukum oleh Hakim dalam Perspektif Hukum Progresif, Sinar Grafika, Jakarta, hlm. 6

${ }^{23}$ Badan Pembinaan Hukum Nasional, Hakim Komisaris dalam Sistem Peradilan di Indonesia, Jakarta: BPHN, 2011, hlm. 2-3.
} 
dengan memasukkan "penetapan tersangka" sebagai unsur objek norma (normgedrag) baru dalam rangkaian Pasal 77 huruf a KUHAP menjadi kewenangan praperadilan dengan mengabaikan keadilan prosedural yang menuntut penegakan terhadap asas-asashukum dalam penggunaan metode interpretasi di pertimbangan hukumnya. Asas-asas hukum tersebut meliputi asas Noscitur a Sociis, asas Ejusdem Generis dan asas Expressio Unius ExclusioAlterius yang merupakan asas yang terkandung dalam prinsip contextualism.

2. Terkait aspek kepastian hukum, dapat dikemukakan bahwa putusan perkara aquo selain tidak sesuai dengan asas yang terkandung dalam prinsip contextualism, juga bertentangan dengan asas legalitas yang terkandung dalam Pasal 3 KUHAP. Hal ini dikarenakan hakim praperadilan telah melakukan analogi terhadap kewenangan lembaga praperadilan dengan menetapkan "penetapan tersangka" sebagai unsur obyek norma (normgedrag) baru didalamnya. Putusan a quo akan mengganggu kepastian hukum dalam tatanan sistem hukum karena terdapat suatu konstruksi hukum baru yang tidak sesuai secara penalaran metode argumentum a'contrario terhadap rujukan dalam Pasal 77 huruf a KUHAP dan hal tersebut bertentangan dengan asas legalitas dalam lapangan hukum pidana.

Hakikat pemeriksaan permohonan praperadilan sesungguhnya adalahpemeriksaan yang bersifat pemenuhan syaratformalitas, karena lembaga praperadilantidak memeriksa pokok perkara suatu perkarapidana. Ketidakpatuhan terhadap asas-asashukum dengan tanpa memperhatikankesesuaian dengan hukum (rechmatigheid)dalam membuat pertimbangan hukum suatuputusan pemeriksaan perkara pidana termasukpermohonan praperadilan akan mencederaiperasaan keadilan dari hukum itu sendiri.Penegakan asas-asas hukum secara baikdengan 
penggunaan metode interpretasi yangtepat dalam logika hukum pertimbangan hakimpraperadilan akan menjamin kepastian hukumdari suatu putusan. Dalam putusan pidana,penerapan asas legalitas seperti yang dianutdalam Pasal 3 KUHAP merupakan prasyaratpenting, selain itu harus diperhatikan bahwatidak diperkenankannya penggunaaan metodeinterpretasi analogi dalam lapangan hukumpidana.Oleh karenanya, guna mengantisipasidampak dari Putusan Praperadilan Nomor: 04/Pid.Prap/2015/PN.Jkt.Sel., Mahkamah AgungRI perlu menggunakan fungsi pengawasannyauntuk memastikan setiap hakim mematuhihukum acara pidana guna terjaminnya prinsipkeadilan dan kepastian hukum dalam putusanyang dikeluarkan. Dan bagi pembentukundang-undang (Pemerintah dan DPR)untuk secepatnya merevisi ketentuan tentangpraperadilan yang diatur dalam KUHAP.

Namun pada eksepsinya, termohon yang dalam hal ini Komisi Pemberantasan Korupsi (KPK) menganggap bahwa objek permohonan daripada pemohon bukanlah wewenang daripada Hakim Praperadilan. Dan di dalam pertimbangan sebelum menjatuhkan putusannya, Hakim Sarpin Rizaldi berpandangan bahwa penetapan tersangka merupakan bagian dari rangkaian tindakan penyidik dalam proses penyidikan, dimana penetapan sebagai tersangka merupakan bagian dari upaya paksa, maka lembaga hukum yang berwenang menguji keabsahan penetapan tersangka adalah lembaga praperadilan. Sehingga berdasarkan putusan tersebut, melepas status tersangka dari Budi Gunawan. Putusan tersebut apabila dijadikan sumber hukum oleh hakim lain atau yurisprudensi, tentunya akan memiliki dampak dibanding sebelum dikeluarkan putusan.

Perkembangan masyarakat mampu melahirkan perkembangan dan penemuan hukum. Hal ini tentu saja menyangkal pendapat para sarjana di akhir abad ke 19 bahwa hukum merupakan satu kesatuan lengkap yang 
tertutup, di luar Undang-undang tidak ada hukum, dan hakim tak boleh menjalankan keadaan hukum yang tidak disebutkan dalam peraturan perundang-undangan. Namun pada kenyataannya sekarang, terjadi kesatuan pemahaman mengenai sistem hukum yang terbuka, yang diakibatkan oleh kemajuan masyarakat dan berdampak kepada cara berfikir mengenai hukum tersebut menjadi lebih dinamis. ${ }^{24}$

Penemuan hukum menurut Sudikno Mertokusumo diartikan sebagai proses pembentukan hukum oleh hakim atau petugas hukum lain yang diberi tugas melaksanakan hukum terhadap peristiwa hukum yang konkret, artinya penemuan hukum merupakan proses konkretisasi peraturan hukum (das sollen) yang bersifat umum dengan mengingat peristiwa konkret (das sein). ${ }^{25}$

Achmad Ali dalam bukunya mengatakan bahwa ada dua teori penemuan hukum yang dapat dilakukan oleh hakim dalam praktik peradilan, yaitu melalui metode interpretasi dan metode kontruksi. ${ }^{26}$ Dapat dijelaskan mengenai metode interpretasi hukum atau yang disebut dengan penafsiran hukum, yaitu sebagai berikut:

Interpretasi hukum terjadi, apabila terdapat ketentuan undang-undang yang secara langsung dapat ditetapkan pada kasus konkret yang dihadapi, atau metode ini dilakukan dalam hal peraturannya sudah ada, tetapi tidak jelas untuk dapat diterapkan pada peristiwa konkret atau mengandung arti pemecahan atau penguraian akan suatu makna ganda, norma yang kabur (vage normen), konflik antar norma hukum (antinomy normen), dan ketidakpastian dari suatu peraturan

\footnotetext{
${ }^{24}$ Achmad Irwan Hamzani, Law Enforcement Problems and Impacts of the Law Development in Indonesia, International Journal of Psychosocial Rehabilitation, Tahun 2020 Volume 24 (4), hlm 3244. ${ }^{25}$ Sudikno Mertokusumo dan A Pitlo, 1993, Bab-Bab tentang Penemuan Hukum, Citra Aditya Bakti, Jakarta,hlm.4.

${ }^{26}$ Achmad Ali, 1993, Menguak Tabir Hukum (Suatu Kajian Filosofis dan Sosiologis), Chandra Pratama, Jakarta, hlm.167.
} 
perundang-undangan. Interpretasi terhadap teks peraturan perundangundangannya pun masih tetap berpegang pada bunyi teks tersebut. ${ }^{27}$

Metode kontruksi hukum dapat dijelaskan sebagai berikut, Kontruksi hukum terjadi, apabila tidak diketemukan ketentuan undang-undang yang secara langsung dapat diterapkan pada masalah hukum yang dihadapi, atau dalam hal peraturannya memang tidak ada, jadi terdapat kekosongan hukum (recht vacuum) atau kekosongan undang-undang (wet vacuum). Untuk mengisi kekosongan undang-undang inilah, biasanya hakim menggunakan penalaran logisnya untuk mengambangkan lebih lanjut suatu teks undang-undang, dimana hakim tidak lagi berpegang pada bunyi teks itu, tetapi dengan syarat hakim tidak mengabaikan hukum sebagai suatu sistem. ${ }^{28}$

Agar para hakim pengadilan dalam menafsirkan objek praperadilan dalam Pasal 77 KUHAP harus membuka diri, jangan terbelenggu dalam kekakuan. Para hakim pengadilan tidak selamanya harus berprinsip sebagai penyambung lidah atau corong undang-undang yang bersifat absolut untuk menciptakan tujuan kepastian saja akan tetapi harus mampu menggali dan mencari keadilan dengan melakukan interpretasi hukum yang rasional, bukan insting belaka, karena yang demikian itu lebih baik dan bermanfaat dapat memberikan keadilan bagi para pencari keadilan.

\section{E. Simpulan}

Dasar pertimbangan hakim Pengadilan Negeri Jakarta Selatan dalam Putusan Nomor: 04/Pid.Prap/2015/PN.Jkt.Sel., yang memutuskan penetapan status tersangka terhadap pemohon tidak sah dan tidak berdasarkan atas hukum pada prinsipnya telah memenuhi tujuan mencari keadilan dalam menentukan objek praperadilan. Hakim menginterpretasi objek praperadilan secara luas

\footnotetext{
27Jazim Hamidi, 2005, Hermeneutika Hukum (Teori Penemuan Hukum Baru dengan Interpretasi Teks), UII Press, Yogyakarta, hlm.52.

${ }^{28}$ Ibid, hlm.38.
} 
dengan menggunakan interpretasi sosiologis (teleologis) dan interpretasi argumentum peranalogiam, sehingga mamasukkan penetapan status tersangka sebagai objek praperadilan. Putusan tersebut juga memenuhi tujuan kepastian karena hakim dalam menentukan subjek delik korupsi sesuai dengan perundangundangan yang berlaku. Hakim mendasarkan pertimbangannya pada Pasal 6 junto Pasal 11 UUKPK, dan Pasal 1 angka 1 junto Pasal 2 UU Anti KKN dikaitkan dengan jabatan pemohon. Subjek delik korupsi secara umum dalam UUPTPK maupun dalam UU Anti KKN telah diekstensifikasi (diperluas) maknanya meliputi pegawai negeri, penyelenggara negara, aparat penegak hukum, dan setiap orang termasuk masyarakat sipil. Untuk memahami kategori pegawai negeri dan penyelenggara negara dalam kedua undang-undang saling komplementer (melengkapi) agar tidak ada satupun orang yang kebal hukum. Akan tetapi hakim mempersempit (interpretasi restriktif) subjek delik korupsi dalam Pasal 2 angka 7 UU Anti KKN karena yang boleh ditangani oleh KPK adalah hanya pegawai negeri atau penyelenggara negara yang memiliki jabatan Eselon I dan pejabat lain yang disamakan di lingkungan sipil, militer, dan Polri. Bukan hakim Pengadilan Negeri Jakarta Selatan yang mempersempit makna penyelenggara negara tetapi Universitas Sumatera Utara pembuat undangundang lah yang mempersempitnya dalam rangka untuk koordinasi dan supervisi (vide: Pasal 6 huruf a dan b UUKPK). Akan tetapi hakim yang mempertimbangkan tentang kerugian keuangan negara dalam perkara aquo pada prinsipnya bertentangan dengan hakikat praperadilan itu sendiri.Hakim juga menggunakan interpretasi argumentum peranalogiam, dengan memperluas objek sidang praperadilan yaitu memeriksa materi pokok perkara padahal memeriksa materi pokok perkara merupakan lingkup peradilan bukan praperadilan.Hakim yang memeriksa materi pokok perkara seolah-olah ingin membenturkan perkara aquo tersebut pada asas nebis in idem agar suatu saat bila perkara itu diajukan kembali kembali ke persidangan menjadi batal demi hukum. 
Landasan filosofis Praperadilan dalam KUHAP adalah perlindungan Hak Asasi Manusia terhadap tindakan sewenang-wenang penegak hukum dalam penggunaan upaya paksa, yang bisa dilihat dari tiga sisi yaitu pertama, dari sisi penegak hukum, merupakan mekanisme pengawasan terhadap penegak hukum dalam penggunaan upaya paksa pada prosedur penyidikan dan penuntutan. Kedua, dari sisi tersangka, merupakan mekanisme perlindungan HAM yang menjamin terpenuhinya hak hukum tersangka selama proses penyidikan dan penuntutan. Ketiga, dari sisi pengadilan, instrumen penguji apakah penyidik atau penuntut umum melakukan pelanggaran terhadap hak hukum tersangka.

Terkait penetapan tersangka sebagai obyek praperadilan, dua putusan Praperadilan memberikan ratio decidendi yang berbeda yaitu: pertama, dalam ratio decidendi Putusan Praperadilan No.04/Pid.Prap/2015/PN.Jkt.Sel tanggal 16 Februari 2015 atas nama pemohon Budi Gunawan, Hakim berpendapat bahwa penetapan tersangka merupakan obyek praperadilan. Pertimbangan hakim dalam putusan antara lain asas legalitas hanya berlaku dalam hukum pidana materiil dan tidak berlaku untuk hukum acara pidana, sehingga kewenangan Praperadilan sebagaimana diatur dalam pasal 1 butir 10 KUHAP jo. Pasal 77 KUHAP dapat ditafsirkan dan Hakim Praperadilan telah menafsirkan penetapan tersangka sebagai upaya paksa dengan pertimbangan bahwa segala tindakan penyidik dalam proses penyidikan dan segala tindakan Penuntut Umum dalam proses penuntutan adalah merupakan tindakan upaya paksa, karena telah menempatkan dan menggunakan label "pro justisia" pada setiap tindakan.

Kedua, ratio decidendi Putusan Praperadilan No. 18/Pid/Prap/2015/PN.Jkt.Sel tanggal 14 April 2015 dalam perkara atas nama pemohon Suroso Atmomartoyo, Hakim berpendapat bahwa penetapan tersangka bukanlah obyek praperadilan, dengan pertimbangan antara lain: Pasal 1 angka 10 KUHAP jo. Pasal 77 jo. Pasal 82 ayat 1 jo. Pasal 95 ayat 1 dan ayat 2 KUHAP telah diatur jelas dan tegas wewenang yang dimiliki oleh hakim praperadilan dan dari 
kewenangan tersebut tidak termasuk kewenangan untuk mengadili tentang penetapan tersangka maupun tentang penyidikan yang tidak sah, dan tidak diaturnya penetapan tersangka maupun tidak sahnya penyidikan dalam KUHAP bukanlah disebabkan kekosongan hukum, akan tetapi karena KUHAP sendiri sudah dengan jelas membatasi secara limitatif obyek praperadilan, sehingga halhal lain yang tak termuat harus dibaca bukan merupakan obyek praperadilan. Serta, hukum acara pidana mempunyai fungsi yang sangat penting oleh karenanya harus harus bersifat strict, xed, correct dan tidak boleh disimpangi serta harus bersifat imperatif (telah memaksa), sehingga hakim harus tunduk serta terikat pada hukum acaranya dan tidak boleh bebas untuk menafsirkannya. Ratio decidendi Putusan Mahkamah Konstitusi No. 21/PUU-XII/2014 tanggal 28 April 2015 Hakim berpendapat bahwa penetapan tersangka adalah obyek praperadilan, dengan pertimbangan bahwa KUHAP tidak memiliki check and balance system atas tindakan penetapan tersangka oleh penyidik karena KUHAP tidak mengenal mekanisme pengujian atas keabsahan perolehan alat bukti, dan untuk memberikan hak yang seimbang sebagai perwujudan penghargaan hak asasi manusia. Hal ini didasarkan pada pemikiran bahwa Indonesia adalah negara hukum sebagaimana disebutkan dalam Pasal 1 ayat 3 UUD NRI 1945, dalam negara hukum, asas due process of law sebagai salah satu perwujudan pengakuan hak asasi manusia, dalam proses peradilan pidana menjadi asas yang harus dijunjung tinggi oleh semua pihak terutama bagi lembaga penegak hukum.

Ketentuan hukum acara pidana yang mengatur tentang ruang lingkup wewenang praperadilan dalam Pasal 77 KUHAP tidak bisa hanya ditafsirkan secara kaku dan terbelenggu hanya pada sah tidaknya penangkapan, penahanan, penghentian penyidikan dan penuntutan, ganti kerugian dan rehabilitasi. Hakim tidak lagi mulut undang-undang yang absolut, hakim tidak boleh terbelenggu dengan kekakuan dengan hanya bersandarkan pada asas legalitas dalam menggali dan menemukan keadilan. Berdasarkan interpretasi sosiologis, 
interpretasi peranalogiam (analogi), interpretasi ekstensif, dan interpretasi a contrario, maka penemuan hukum dengan argumentasi yang rasional, bukan insting belaka, memberi peluang untuk menafsirkan objek praperadilan secara luas. Sehingga objek praperadilan bukan saja hanya yang diatur di dalam Pasal 77 KUHAP tetapi juga meliputi semua tugas dan wewenang yang menjadi domainnya penyidik dan penuntut umum. Praperadilan berarti sebelum peradilan dilaksanakan, oleh karena itu, penyitaan, penggeledahan, dan penetapan status tersangka masuk dalam objek praperadilan.

\section{Daftar Pustaka}

\section{Buku}

Agus, Bustanudin, 1999, Pengembangan Ilmu-Ilmu Sosial Studi Bidang Antara Pandangan Ilmiah dan Ajaran Islam, Jakarta: Gema Insani.

Amirudin dan Asikain, Zaenal, 2004, Pengantar Metodologi Hukum, Jakarta: PT. Radja Grafindo Persada.

Asshiddiqie, Jimly, dan Safa'at, Ali, 2012, Teori Hans Kelsen Tentang Hukum, Jakarta: Konpress,

Bisri, Ilham, 2014, Sistem Hukum Indonesia, Prinsip-Prinsip E Implementasi Hukum di Indonesia, Jakarta: PT. Raja Grafindo Persada.

Badan Pembinaan Hukum Nasional, 2011, Hakim Komisaris dalam Sistem Peradilan di Indonesia, Jakarta: BPHN.

Emong Sapardjaja, Komariah, Kajian dan Catatan Hukum atas Putusan Praperadilan No.04/Pid.Prap/2015/PN.Jkt.Sel Tertanggal 16 Februari 2015 Pada Kasus Budi Gunawan:Sebuah Analisis Kritis, Padjadjaran Jurnal Ilmu Hukum Volume 2 Nomor 1 Tahun 2015

Harikunto, Suharsini, 2014, Prosedur Penelitian (satu pendekatan praktek), 1993, Jakarta: Rieneka Cipta.

Hamzah, Andi, 2008, Hukum Acara Pidana Indonesia,Jakarta: Sinar Grafika. 
Harahap, Yahya, Pembahasan Permasalahan dan Penerapan KUHP, Jakarta: Sinar Grafika,

Ismail, Maqadir, SF. Marbun, Ikhsan, Mohammad,2017, Himpunan Putusan Tentang Praperadilan, Yogyakarta: FH UII Press.

Kelib, Abdullah, 1995, Metode Penelitian Fiqh dan Hukum Sekuler'dalam Majalah MasalahMasalah Hukum, Fakultas Hukum Universitas Diponegoro Semarang.

Kansil.C.T.S, 2011, Pengantar Ilmu Hukum Indonesia, Jakarta: Rineka Cipta.

Lebacqz, Karen, 2015, Teori-teori Keadilan, Bandung:Penerbit Nusa Media.

Mursanef ,Murseh, 1981, Pedoman Membuat Skripsi, Jakarta: Haji Mas Agung.

Nonet, Philipe \& Selznick, Philip, 2003, Hukum Reponsif. Pilihan di Masa Transisi, terjemahan Rafael EdyBoscodari LawE Society in Transition: Toward Responsive Law, Jakarta: Huma.

Rumokoy, Donal Albert, 2014, Frans Maramis, Pengantar Ilmu Hukum, Jakarta: PT. Raja Grafindo Persada.

Rifai Ahmad, 2010, Penemuan Hukum oleh Hakim dalam Perspektif Hukum Progresif, Jakarta: Sinar Grafiika.

Sadi, Muhammad. 2015, Pengantar Ilmu Hukum,Jakarta, Prenadamedia Group.

Sunggono, Bambang,1999,Dalam Metodologi Penelitian Hukum, Jakarta: PT. Radja Grafindo Persada.

Soekamto, Soerjono, Marmudji, Sri, 2004, Penelitian Hukum Normatif :Suatu Tinjauan Singkat, Jakarta: PT. Raja Grafindo Persada.

Tiena Masriani, Yulies, 2013, Pengantar Hukum Indonesia, Jakarta: Sinar Grafika.

Wardanai, Fety Rahmah, Analisis Terhadap Putusan Praperadilan oleh Hakim penetapan Tersangka ditinjau dari Hukum Acara Pidana. (Studi Kasus Putusan Terhadap Tersangka Komjen Pol Budi Gunawan di Pengadilan Negeri Jakarta Pusat), Publikasi Ilmiah. 


\section{Jurnal}

Achmad Irwan Hamzani, Law Enforcement Problems and Impacts of the Law Development in Indonesia, International Journal of Psychosocial Rehabilitation, Tahun 220 Volume 24 (4).

Achmad Irwan Hamzani The Responsive Law Thinking Atmosphere: From the United States to Indonesia, International Journal of Advanced Science and Technology, Tahun 2020, Volume 29 (4).

\section{Peraturan Perundang-Undangan}

Undang-Undang Dasar 1945.

Undang-Undang Nomor 48 Tahun 2009 tentang Kekuasaan Kehakiman.

Putusan Praperadilan No. 04/Pid. Prap/2015/PN.Jaksel.

\section{Artikel}

Mukharom, Jateng Pos, Kolom OPINI, "Sarpin Efect" Mulai Menggejala.Terbit hari Senin, Tanggal 02 Maret 2015. 